\title{
Genome Size and Ploidy of Phlox paniculata and Related Germplasm in Subsections Paniculatae and Phlox
}

\author{
Peter J. Zale ${ }^{1,3}$ and Pablo Jourdan ${ }^{2}$ \\ Ornamental Plant Germplasm Center, 670 Vernon L. Tharp Street, Columbus, OH 43210; \\ Department of Horticulture and Crop Science, The Ohio State University, 2021 Coffey Road, \\ Columbus, OH 43210; and Longwood Gardens, P.O. Box 501, Kennett Square, PA 19348
}

\begin{abstract}
AdDitional INDEX wORDs. flow cytometry, chromosome number, accession, diploid, tetraploid, triploid, phylogeny
Abstract. Phlox is an important genus of herbaceous ornamental plants previously targeted for germplasm development, characterization, and enhancement by the U.S. Department of Agriculture, National Plant Germplasm System. Among Phlox in cultivation, Phlox paniculata is the most widely grown and intensively bred species, but little is known about variation in genome size and ploidy of this species or of related taxa that may be used for germplasm enhancement. The objective of this study was to assess cytotype variation in a diverse collection of cultivars and wild germplasm of $P$. paniculata (subsection Paniculatae) and of related taxa in subsections Paniculatae and Phlox. The collection included 138 accessions from seven species and two interspecific hybrids. Flow cytometry was used to estimate holoploid (2C) genome sizes and to infer ploidy levels. Chromosome counts were made to calibrate ploidy with genome size for a subset of taxa. Most cultivars were diploid $(2 n=2 x=14)$ and had mean genome sizes that did not vary between subsections Paniculatae (14.33 pg) and Phlox (14.23 pg) although size variation was greater among cultivars within subsection Phlox. Triploid cultivars of $P$. paniculata, with a mean genome size of $21.36 \mathrm{pg}$ and mitotic chromosome counts of $2 n=3 x=21$, were identified. Such triploids suggests previous interploid hybridization within this taxon. Five tetraploid $(2 n=4 x=28)$ cultivars were found in subsection Phlox; all were selections of $P$. glaberrima ssp. triflora, and had a mean genome size of $25.44 \mathrm{pg}$; chromosome counts in one of these confirmed they were tetraploid. The putative hybrid Phlox Suffruticosa Group 'Miss Lingard' showed an intermediate genome size of $21.21 \mathrm{pg}$ supporting a triploid, hybrid origin of this taxon. Mean $2 \mathrm{C}$ genome sizes among wild-collected accessions were similar to values reported for cultivars $($ Paniculatae $=14.59 \mathrm{pg}$, Phlox $=14.23 \mathrm{pg})$, but taxa in subsection Phlox exhibited greater variation that included two tetraploids identified among wild-collected accessions; one, of $P$. pulchra, had a mean genome size of $26.17 \mathrm{pg}$, representing the first report of polyploidy in the taxon. This is the first report on genome size for the majority of species in the study. Although genome size could not be used to differentiate taxa in subsections Paniculatae and Phlox, the data provide further insights into cytotype variation of Phlox germplasm useful for plant breeders and systematists.
\end{abstract}

Phlox (Polemoniaceae) is a phenotypically diverse genus with substantial interpopulation differentiation for numerous morphological characters and ploidy; it includes $\approx 65$ species with centers of diversity in the eastern and western United States (Wherry, 1955). The most important horticultural forms of Phlox are found in the eastern species, which are taxonomically distributed among three sections (Annuae, Occidentales, and Phlox) and six subsections (Divaricatae, Subulatae, Phlox, Paniculatae, Stoloniferae, and Cluteanae) based on variations in the calyx, style length, and geographic distribution (Wherry, 1955). Subsections Paniculatae and Phlox include species having a style that exceeds $15 \mathrm{~mm}$ in length and that is as long as, or longer than, the corolla tube (Fig. 1) (Wherry, 1955). This

Received for publication 20 Mar. 2015. Accepted for publication 2 July 2015. Salaries and research support were provided by state and federal funds appropriated to the Ohio Agriculture Research and Development Center, The Ohio State University, as well as by the Floriculture and Research Initiative in support of the Ornamental Plant Germplasm Center.

We thank Dr. D.W.H. Robarts and the staff of the Ornamental Plant Germplasm Center for assistance with flow cytometry. Dr. D. Struve and Dr. L. McHale provided valuable comments and Dr. J.J.N. Campbell and A. Floden assisted in field work and accession collection.

${ }^{1}$ Breeder and Curator of Plants at Longwood Gardens.

${ }^{2}$ Associate Professor.

${ }^{3}$ Corresponding author. E-mail: zale.6@buckeyemail.osu.edu. feature differentiates these species from all other Phlox taxa that are collectively known as "long-styled" phloxes. Style length has been suggested as a possible barrier to interspecific hybridization among species of Phlox that differ for the trait, but this has not been rigorously tested and documented (Levin, 1966; Locklear, 2011; Symons-Jeune, 1953).

Among long-styled phloxes, P. amplifolia and P. paniculata comprise subsection Paniculatae, and are distinguished from taxa in subsection Phlox by their areolate leaf veins, white or cream-colored pollen, and pubescent calyces (Fig. 1; Table 1). Subsection Phlox contains up to six species, but the taxonomy of this group has been historically confused and revised several times; a well-resolved taxonomy or phylogeny does not yet exist. The taxonomic confusion is caused by extensive intraspecific variation prevalent in Phlox carolina and P. glaberrima, which has led some to refer to these as the P. carolina$P$. glaberrima complex, but more recently referred to as the "P. glaberrima complex" (Ferguson and Jansen, 2002; Ferguson et al., 1999; Wherry, 1932a, 1932b, 1945, 1955). These species are phenotypically similar to those in subsection Paniculatae, but are differentiated by having obscure leaf veins, yellow pollen, and glabrous calyces (Fig. 1; Table 1). To some degree, the taxa can be further distinguished from each other on the basis of morphology, geographic distribution, and habitat preference, but the traditional morphological characters used 

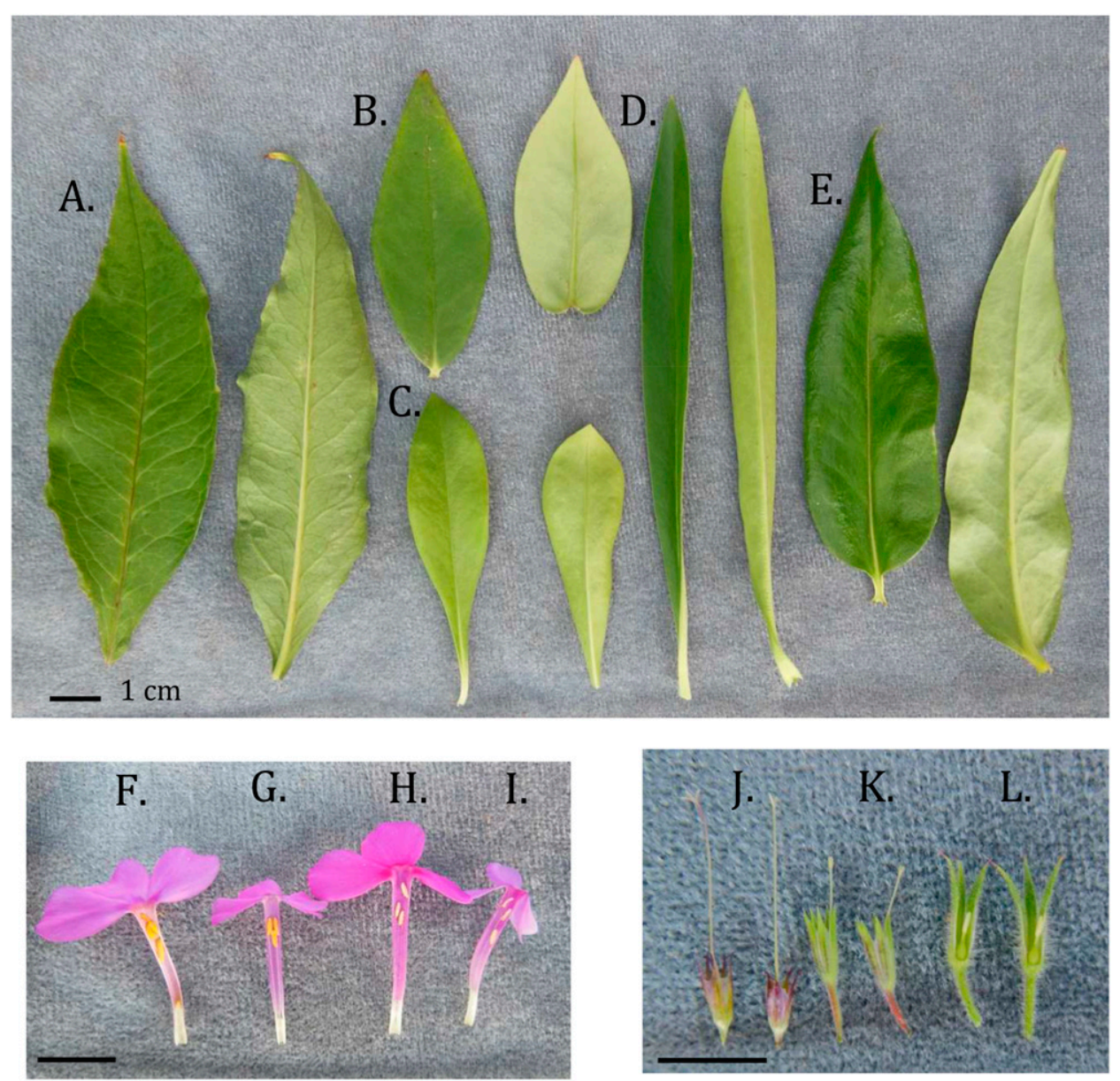

Fig. 1. (A-L) Leaf, pollen, and style length variation of Phlox taxa. (A-E) Differences in leaf shape between P. paniculata and the "P. glaberrima complex": (A) P. paniculata PZ10-209, note the areolate leaf veins; (B) Phlox carolina ssp. alta PZ10-045, note obscure leaf veins; (C) P. glaberrima ssp. triflora PZ10-193; (D) P. glaberrima ssp. triflora PZ11-019; (E) P. maculata PZ12-107. (F-I) Differences in pollen color between subsection Paniculatae and Phlox: (F) yellow pollen of P. glaberrima ssp. triflora PZ11-019; (G) yellow pollen of P. maculata PZ12-107; (H) cream-colored pollen of P. paniculata PZ10-209; (I) cream-colored pollen of P. amplifolia PZ11-050. (J-K) Differences in style length among Phlox subsections: (J) subsection Paniculatae and Phlox, $(\mathbf{K})$ subsection Subulatae, $(\mathbf{L})$ subsection Divaricatae; scale bar $=1 \mathrm{~cm}$.

2011; Symons-Jeune, 1953; Wherry, 1955). Cultivars have been primarily selected for variations in flower color, duration of flowering period, and variegated foliage. One cultivar, David, was chosen as the 2002 "Perennial Plant of the Year" by the Perennial Plant Association because of its adaptability to different climatic regions, soil types, and disease resistance. Phlox paniculata continues to be the focus of breeding programs, and cultivars are still introduced annually. The closely related $P$. amplifolia has rarely been introduced into cultivation, although European nurseries have reputedly developed cultivars (Deam, 1940; Wherry, 1935a). However, because of gross morphological similarity of $P$. amplifolia to $P$. paniculata, the true identity of these cultivars has yet to be demonstrated, and the breeding potential of $P$. amplifolia remains largely unknown.

In contrast to the taxonomic stability of subsection Paniculatae, taxa within the morphologically divergent " $P$. glaberrima complex" of subsection Phlox have been the subject of debate, frequent change, and taxonomic confusion (Ferguson and Jansen, 2002; Ferguson et al., 1999; Locklear, 2011; Wherry, 1935b, 1945, 1955). The traditional morphological markers (calyx, vesture, and leaf size/shape) used to differentiate species and subspecies in related subsections, cannot be used to delineate taxa of this com-

to differentiate them overlap and render identification of wildcollected germplasm difficult, if not impossible (Table 1). Extensive phenotypic variation within these two subsections has resulted in the selection of cultivars and putative interspecific hybrids, but the potential for further breeding and selection in this group remains unrealized, and has likely been hindered by lack of phylogenetic and taxonomic resolution. Genome size and ploidy estimation provide an additional criterion for assessing phylogenetic relationships among these phloxes, and to identify potential breeding barriers to hybrid cultivar development.

The taxonomy of subsection Paniculatae has remained stable since formal recognition, but phenotypic variation in P. paniculata has resulted in selection of over 800 cultivars (Bendtsen, 2009; Fuchs, 1994; Lierval, 1866; Locklear, 2011; Pridham, 1934; Symons-Jeune, 1953; Wherry, 1933, 1935a). Far more cultivars have been selected from this species than any other in the genus. Many of these are still grown, but several have also been lost to cultivation, reintroduced under different names, or have not been introduced in some regions, like the United States (Bendtsen, 2009; Hawke, 2011, 2013; Locklear, plex (Fig. 1; Table 1). In his final attempt to resolve historical taxonomic confusion, Wherry (1955) recognized two primary species, P. carolina and P. glaberrima, and six intraspecific taxa that were described on the basis of morphology, geographic distribution, and habitat preference. Molecular analysis of the "P. glaberrima complex" and related eastern taxa from other subsections using data from the internal transcribed spacer (ITS) region of ribosomal DNA and chloroplast DNA (cpDNA) restriction sites resulted in a paraphyletic grouping and included species from at least three subsections (Ferguson and Jansen, 2002; Ferguson et al., 1999). These studies underscore the concept of a species complex where a single, widespread, but polymorphic taxon is recognized. Previous data indicate that this polymorphism likely resulted from hybridization, but recent evolutionary divergence could produce similar results. More recently, Locklear (2011) recognized $P$. carolina and $P$. glaberrima as distinct, and described one subspecies for each species based on morphology, but also indicated $P$. carolina was “ . ... an enigma ... its distinctiveness as a species appears to have been more apparent in the past than it is today." In our experience, Wherry's intraspecific 


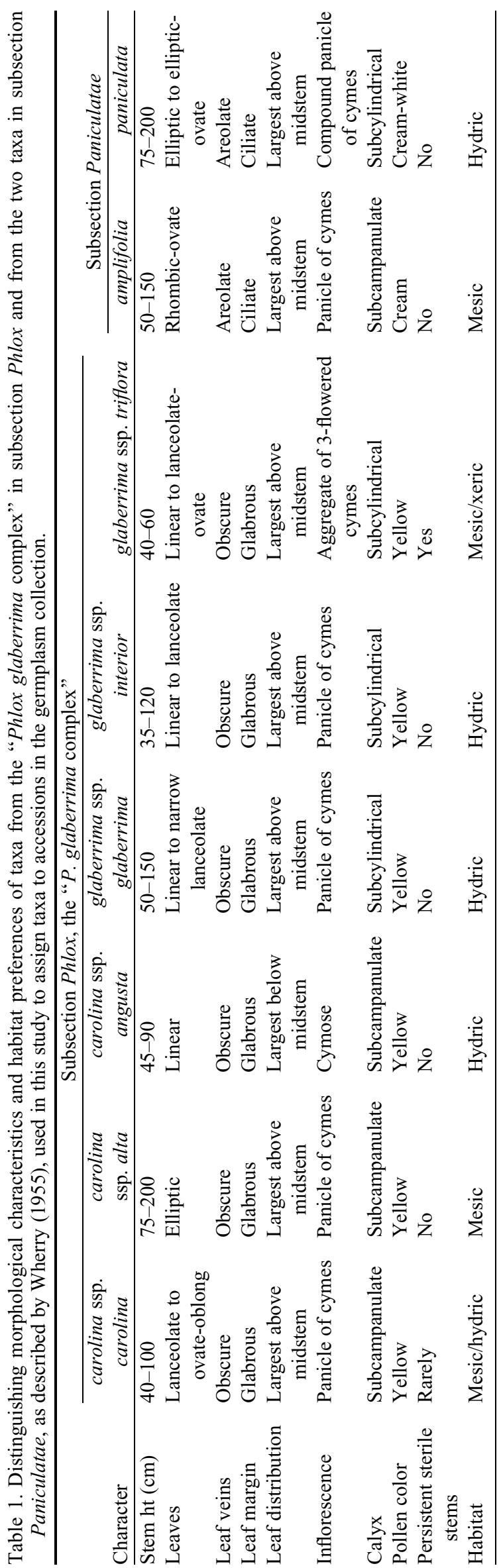

taxonomy based on morphological features does not consistently separate taxa, complicating germplasm collection and characterization efforts within these polymorphic taxa. Thus, the taxonomy or phylogeny is not resolved for morphologically similar taxa in this group. As these taxa reportedly share a close phylogenetic relationship with subsection Paniculatae, there is a need to clarify the relationships. This confusion may adversely affect breeding efforts, and highlights the need for a resolved molecular phylogeny and the use of additional markers, such as genome size and ploidy.

A potentially confounding factor in the taxonomic relationship of these species is the recent evidence for extensive cytotype variation in populations of other Phlox species, including tetraploids in Phlox pilosa; tetraploids, pentaploids, and hexaploids in Phlox amabilis and Phlox woodhousei; tetraploids and hexaploids in Phlox nana; and tetraploids in Phlox subulata (Fehlberg and Ferguson, 2012a; Flory, 1934; Smith and Levin, 1967; Worcester et al., 2012; Wright, 2014). We have also identified polyploid populations of $P$. pilos $a$ and P. subulata (Zale, 2014). In all cases where polyploid Phlox have been identified, the plants did not exhibit obviously altered overall morphology (e.g., the "gigas" effect), and could thus be classified as cryptic polyploids (Fehlberg and Ferguson, 2012a; Worcester et al., 2012). Both the uncertain taxonomic status of $P$. carolina and $P$. glaberrima coupled with the likelihood that cytotype variation is more common in Phlox than previously thought, suggest that an analysis of genome size and inferred ploidy in other Phlox species could further enhance the understanding of the breeding potential in the genus.

Polyploidy has played an important role in the development of ornamental plant cultivars (Contreras et al., 2009; Parris et al., 2010; Ranney, 2006), but the extent to which it has been used in Phlox is uncertain. We could find no published reports about genome sizes for any Phlox cultivars and comparatively few for Phlox species although chromosome counts have been reported for the principal species (Flory, 1931, 1934; Meyer, 1944). A chromosome number survey of over 100 cultivars of $P$. paniculata using meristematic tissue isolated from branch tips determined that all had the diploid $(2 n=2 x=14)$ number, but that certain cultivars exhibited varying numbers of chromosomal fragments (Flory, 1931, 1934; Meyer, 1944). The number of chromosomal fragments varied between squash preparations and was not repeatable, which makes the origin, confirmation, and significance of these fragments unclear. Polyploidy in $P$. paniculata is unknown, but this observation is based on a limited number of cultivars. Observations and comments by various growers and gardeners indicate that fruit and seed production in some cultivars is absent to very low, which could be a consequence of different factors including alterations in ploidy (Bendtsen, 2009; Wherry, 1935a). Determination of genome size and ploidy level in a wide range of cultivars would be of benefit to $P$. paniculata breeders and may have the potential to produce new breeding lines with novel, useful traits (Hawke, 2011; Locklear, 2011).

Differences in ploidy between species are a potent prezygotic barrier to hybridization and are known to affect speciation and evolution by contributing to ecotypic isolation, novel gene expression, and divergence (Eeckhaut et al., 2006; Hogenboom and Mather, 1975; Parris et al., 2010; Ranney, 2006). Knowledge of ploidy is crucial for characterization of germplasm collections and for directing interspecific hybridization efforts. Although genome size and ploidy has been characterized in 
some Phlox species, estimates for several taxa remain undocumented (Bennett and Leitch, 2012). The positive correlation generally established between genome size and ploidy in a number of genera has facilitated rapid and extensive study of cytotypic variation, not only between species but also between populations of a species (Greilhuber and Leitch, 2013). Flow cytometry provides a well-established, rapid method for estimating genome size in plants, and such estimates can be used to infer ploidy when chromosome counts are limited or difficult to generate (Doležel, 2009; Doležel et al., 1998; Parris et al., 2010). Analysis of genome size in populations of Dianthus broteri (Balao et al., 2009), P. pilosa (Worcester et al., 2012), Ranunculus parnassifolius (Cires et al., 2009), and others have demonstrated the existence of intraspecific cytotypic variation between populations that may have an adaptive value (Greilhuber and Leitch, 2013; Šmarda and Bureš, 2010). Thus, it cannot be assumed that individuals in different populations of a taxon necessarily have the same genome size or ploidy level.

The objective of this study was to survey the genome size in a diverse germplasm collection of Phlox that included the longstyled taxa in subsections Paniculatae and Phlox, to infer ploidy and assess cytotype variation both within and between species. Validation of inferred ploidy with chromosome counts would reinforce the characterization of the collection, and provide baseline information for use by Phlox breeders.

\section{Materials and Methods}

Phlox collection. Living plants were obtained from nursery sources and from collection sites in the east-central United States. Emphasis was placed on gathering a diverse collection of $P$. paniculata cultivars readily available in the United States. Many older cultivars cited in the literature are not commercially available, or have been altogether lost to cultivation. Cultivar names were verified using a variety of sources (Bendtsen, 2009; Fuchs, 1994; Locklear, 2011; Meyer, 1944; Pridham, 1934; Symons-Jeune, 1953; Wherry, 1955). Nearly all $P$. paniculata cultivars were selected for unique flower colors and/or patterns, and this served as the primary means of identification. Where possible, some cultivars were obtained from more than one source to confirm identification, but most cultivars are rarely grown and could only be obtained from a single source. The identity of wild-collected material was confirmed using the taxonomic keys of Locklear (2011) and Wherry (1955), information from the phylogenetic analyses of Ferguson et al. (1999) and Ferguson and Jansen (2002), and comparison with herbarium specimens from herbaria at The Ohio State University, University of Kentucky, and West Virginia University. Herbarium vouchers of the collections are maintained at the Ornamental Plant Germplasm Center (OPGC), Columbus, OH.

Plant Cultivation. Plants were grown in 16-cm-wide $\times$ 14.5-cm-deep round, plastic containers in Metro Mix 360 (Scotts Co., Marysville, $\mathrm{OH}$ ) on greenhouse benches in a temperature regime of $22.2 \pm 6{ }^{\circ} \mathrm{C}$ during the day and $18 \pm 3{ }^{\circ} \mathrm{C}$ at night. Nutrients were supplied using $15 \mathrm{~N}-3.9 \mathrm{P}-9.9 \mathrm{~K}$ pelleted, slow-release fertilizer containing micronutrients (Osmocote ${ }^{\circledR}$; Scotts Co., Marysville, $\mathrm{OH}$ ). Samples from these plants were used for chromosome and flow cytometry analysis.

ISOLATION OF NUCLEI AND GENOME SIZE ANALYSIS. Preparation of samples for flow cytometry was done following procedures of Arugumanathan and Earle (1991) and Doležel et al. (1998). In brief, leaf tissue was collected on the day of the analysis, and consisted of fully expanded, disease-free leaves from the upper one-half of the plants. Three samples were prepared for each taxon; a minimum of one plant was used for cultivars, and up to three individuals were tested for wild-collected accessions. Approximately $2 \mathrm{~cm}^{2}$ of Phlox newly expanded leaves and $\approx 0.5 \mathrm{~cm}^{2}$ of Pisum sativum 'Ctirad' leaf tissue were placed in a plastic petri dish, $1 \mathrm{~mL}$ cold buffer containing propidium iodide flourochrome [Solution A (Arugumanathan and Earle, 1991)] was added, and the leaves were chopped concurrently with a new single-edge razor blade. The nuclei suspensions were then filtered through a 70- $\mu$ m nylon cell strainer (BD Falcon, Bedford, MA) into a $1.5-\mathrm{mL}$ microfuge tube to remove debris, and centrifuged at $17,000 \mathrm{~g}_{\mathrm{n}}$ for $20 \mathrm{~s}$. The supernatant was discarded and the remaining pellets were resuspended in $200 \mu \mathrm{L}$ of Solution B (Arugumanathan and Earle, 1991). Samples were then incubated in a $37^{\circ} \mathrm{C}$ water bath for 15 min to digest RNA and subsequently kept on ice until analyzed. Flow cytometry was done with a flow cytometer (FACSCalibur; BD, Franklin Lakes, NJ). Sample runs were considered complete once 10,000 events had been reached, and a minimum of 3000 nuclei had been analyzed. Data collected from each sample was analyzed with CellQuest Pro V (BD Biosciences, San Jose, CA). Genome size was calculated as described by Doležel (2009) using a value of $8.76 \mathrm{pg}$ for the $2 \mathrm{C}$ DNA content of the pea reference (Doležel et al., 1998; Greilhuber et al., 2007) where 2C represents the holoploid, or complete, genome size.

Cytological analysis. Both meiotic (flower bud) and mitotic (root tip) tissues were used to determine chromosome numbers. Root tips were initially treated with $0.002 \mathrm{M}$ 8-hydroxyquinoline (Thermo Fisher Scientific, Waltham, MA) for 2 to $4 \mathrm{~h}$ to accumulate condensed mitotic metaphase chromosomes and then rinsed three times with distilled water. Treated root tips or freshly harvested immature flower buds were fixed in a 3:1 (v/v) solution of $100 \%$ ethanol $(\mathrm{EtOH})$ : glacial acetic acid for 1 to $2 \mathrm{~h}$ at room temperature. Samples were subsequently rinsed in distilled water and either used immediately for observation or stored in $95 \% \mathrm{EtOH}(\mathrm{v} / \mathrm{v})$ at $2{ }^{\circ} \mathrm{C}$. Excised anthers were macerated and stained in $1 \%$ acetocarmine solution for $5 \mathrm{~min}$; the cover slip was placed and slides were gently heated over a flame until the cover slip became cloudy. After cooling, the slide was squashed with direct pressure for at least $1 \mathrm{~min}$ before visualization. Root samples were softened in $1 \mathrm{M} \mathrm{HCl}$ for 10 to $20 \mathrm{~min}$ and then stained in $1 \%$ acetocarmine solution for at least $1 \mathrm{~h}$ at room temperature. Root tips were excised under a dissecting microscope, placed on a microscope slide in two drops of $1 \%$ acetocarmine, heated, and squashed as mentioned above. Chromosomes were visualized at $\times 1000$ in a microscope (IM20; Zeiss United States, Peabody, MA). A minimum of 10 cells displaying metaphase chromosomes were used to confirm chromosome counts.

Statistical ANAlysis. Data for monoploid genome sizes were subjected to analysis of variance by subsection and species, and means were separated using Fisher's least significant difference (Proc GLM, SAS verison 9.3; SAS Institute, Cary, NC).

\section{Results}

A total of 414 samples representing 138 accessions of 15 Phlox taxa from two subsections (Phlox and Paniculatae) were 
analyzed (Tables 2 and 3). We measured genome size in 85 accessions of wild species, cultivars, and hybrids from subsection Paniculatae. In subsection Phlox, 53 accessions from five species were analyzed: 37 were collected from natural plant populations and 16 were cultivars.

The flow cytometric analysis revealed plants with DNA content or genome size equivalent to diploid, triploid, and tetraploid levels (Tables 2 and 3). There was little variation between samples of a single accession, and none of the samples had a $\mathrm{CV}$ greater than 5\%; the mean $\mathrm{CV}$ of all 414 samples was $1.65 \%$ (Tables 2 and 3). The flow cytometry histograms for every Phlox sample consistently displayed two peaks, and normal readouts included a well-defined $\mathrm{G}_{1}$ peak and a reduced $\mathrm{G}_{2}$ peak for the Phlox, and also a prominent $\mathrm{G}_{1}$ peak of the internal standard P. sativum 'Ctirad' (Fig. 2). To validate our methodology, four Phlox species with different mean genome sizes, P. buckleyi (21.36 pg), P. pilosa ssp. pilosa (12.00 pg), $P$. paniculata (13.92 pg), and $P$. subulata $(7.44 \mathrm{pg})$, were processed concurrently and analyzed to verify the position and placement of peaks in relation to each other (Fig. 3). Such concurrent analysis of samples in the absence of a reference genome reduces variation that may be found in individual samples and reinforces calibration with the internal standard (Doležel, 2009). The analysis confirmed the spacing of measured peaks with the $P$. sativum standard and correlates with estimated genome sizes as shown in Tables 2 and 3.

Genomes Size in Subsection Paniculatae. Of the 70 cultivars of $P$. paniculata and two of $P$. $\times$ arendsii, 68 had a mean genome size of $2 \mathrm{C}=14.22 \mathrm{pg}$ with a range of 13.70 to $15.01 \mathrm{pg}$, that varied by $9.50 \%$; these sizes correspond to a diploid level $(2 n=2 x=14)$ that was confirmed with chromosome counts from root tips or pollen mother cells (Fig. 2; Table 3). Cultivars described as $P$. ×arendsii ( $P$. paniculata $\times P$. divaricata), had a genome size essentially indistinguishable from that of $P$. paniculata even though the putative parental species differed in genome size. Progeny obtained from a cross between the putative progenitor species of $P$. xarendsii at the OPGC displayed an intermediate genome size that differs from the cultivars (Zale, 2014). Four cultivars of $P$. paniculata (Blushing Bride, Dick Weaver, John Fanick, and Robert Poore) had a mean genome size of $2 \mathrm{C}=21.36 \mathrm{pg}$, with a range of 20.95 to $21.75 \mathrm{pg}$ and that varied by $3.8 \%$. These sizes are intermediate to the diploid (14.22 pg) and calculated tetraploid (25.92 pg) levels. Analysis of chromosomes in pollen mother cells and dividing root tips at metaphase showed that chromosome number of these taxa is $2 n=3 x=21$, suggesting that they are triploids (Fig. 2; Table 3).

In addition to the genome size analyzed in cultivars from subsection Paniculatae, a collection of 13 accessions obtained from natural populations of $P$. amplifolia (five different sources) and $P$. paniculata (eight different sources) was also examined (Table 3). Mean genome size of $P$. amplifolia $(2 \mathrm{C}=$ $14.29 \mathrm{pg})$ was equivalent to that of $P$. paniculata $(2 \mathrm{C}=14.02$ pg). Overall, the 13 accessions had a mean genome size of $14.12 \mathrm{pg}$ with a range of 13.23 to $14.65 \mathrm{pg}$, and $10.80 \%$ variation (Table 3 ); these wild-derived collections are consistent with diploid levels $(2 n=2 x=14)$ and the sizes equivalent to those of the diploid cultivars. Tetraploids have not yet been identified in wild-collected or cultivated accessions of taxa in Paniculatae although artificial tetraploids have been created (Matiska and Vejsadová, 2010). There was no significant difference between $P$. amplifolia and $P$. paniculata in monoploid genome size, but the mean monoploid genome size of subsection Paniculatae was significantly different from that of subsection Phlox (Table 4).

Genome size in Subsection Phoox. There are far fewer cultivars from taxa in subsection Phlox [synonym subsection Ovatae (sensu Wherry, 1955)] than in subsection Paniculatae although the number of species is greater. Sixteen cultivars of $P$. carolina (two), P. glaberrima (eight), P. maculata (three), and $P$. pulchra (one) were included, as well as two cultivars in the Suffruticosa Group, described as hybrids between $P$. carolina and P. maculata (Locklear, 2011). The cultivars of $P$. carolina, $P$. maculata, $P$. pulchra, and one of the Suffruticosa Group ('Monica Lynden-Bell') had genome size equivalent to the diploid level $(2 \mathrm{C}=14.25 \mathrm{pg}$, range $=13.83$ to 15.09 , $11.50 \%$ variation) (Table 2 ). The eight cultivars of $P$. glaberrima differed in genome size such that three of them had diploid-equivalent sizes $(2 \mathrm{C}=14.39 \mathrm{pg})$ and the remaining five had tetraploid-equivalent sizes $(2 \mathrm{C}=25.44 \mathrm{pg})$. All five polyploid cultivars could be keyed to $P$. glaberrima ssp. triflora (Wherry, 1955). Chromosome counts confirmed that these accessions were tetraploid $(2 n=4 x=28)$. Phlox Suffruticosa Group 'Miss Lingard', had a mean genome size of $21.21 \mathrm{pg}$, an intermediate genome size that confirmed the triploid nature of this putative hybrid cultivar (Table 2).

Among wild-collected accessions, the five species differed in mean holoploid genome size at the diploid level: $P$. carolina $(2 \mathrm{C}=14.67 \mathrm{pg}), P$. glaberrima $(2 \mathrm{C}=13.57), P$. maculata $(2 \mathrm{C}=$ $14.15), P$. ovata $(2 \mathrm{C}=11.99)$, and $P$. pulchra $[2 \mathrm{C}=14.12$ (one accession only)], and there were significant differences among monoploid genome sizes among the species (Table 4). Combined, these wild-collected accessions had a mean genome size of $13.83 \mathrm{pg}$ and a range of 11.71 to $15.55 \mathrm{pg}$. The $28.1 \%$ variation in genome size among the diploid taxa in this subsection is larger than that found in subsection Paniculatae. Among the 37 wild populations, we found two species that had genome sizes suggestive of polyploidy, most likely tetraploid, one in $P$. glaberrima ssp. triflora $(2 \mathrm{C}=25.68 \mathrm{pg})$ and the other in P. pulchra $(2 \mathrm{C}=26.17 \mathrm{pg})$ (Fig. 2; Table 3).

\section{Discussion}

We successfully measured nuclear genome size and ploidy of a closely related group of long-styled Phlox species and cultivars found in the germplasm collection at the OPGC and have been able to assess the degree of cytotype variation within and among species. Characterization of genome size within this group has been a prelude to interspecific hybridization studies that are part of a Phlox germplasm enhancement program that encompasses the majority of eastern species (Zale, 2014). The following observations can be highlighted. 1) Wild populations of the seven species in subsections Paniculatae and Phlox were primarily diploid, but tetraploid individuals were identified in P. glaberrima ssp. triflora and P. pulchra. 2) The diploid taxa in both subsections have $2 \mathrm{C}$ genome sizes that are similar, ranging from 13 to $15 \mathrm{pg}$. 3) Cultivars of species in the two subsections could be diploid, triploid, and tetraploid. More than $90 \%$ of the $70 P$. paniculata cultivars examined were diploid, but four novel triploid cytotypes were identified. Cultivars of P. glaberrima ssp. triflora have been selected at the tetraploid level. 4) Although polyploidy appears to be rare in the different species of subsection Phlox, the identification of polyploid cultivars suggests that increased ploidy may be associated with 
Table 2. Relative holoploid (2C) and monoploid (1Cx) genome sizes, and inferred ploidy levels for a diverse collection of cultivars and hybrids of Phlox (section Phlox, subsections Paniculatae and Phlox). Genome size was determined using flow cytometry and inferred ploidy was confirmed by chromosome counts of selected samples.

\begin{tabular}{|c|c|c|c|c|c|c|}
\hline Taxa & Accession no. & Source $^{\mathrm{z}}$ & $\begin{array}{c}\text { Relative } 2 \mathrm{C} \text { genome } \\
\text { size }[\text { mean } \pm \text { SD }(\mathrm{pg})]^{\mathrm{y}}\end{array}$ & $\mathrm{CV}(\%)^{\mathrm{x}}$ & Ploidy $^{\mathrm{w}}$ & $1 \mathrm{C} x$ genome size $(\mathrm{pg})^{\mathrm{v}}$ \\
\hline \multicolumn{7}{|l|}{ Subsection Paniculatae } \\
\hline \multicolumn{7}{|l|}{ Phlox paniculata } \\
\hline 'Anne' & PZ10-068 & $\mathrm{F}$ & $14.51 \pm 0.16$ & 1.62 & $2 x$ & 7.26 \\
\hline 'Balmoral' & PZ12-002 & $\mathrm{F}$ & $13.85 \pm 0.02$ & 1.46 & $2 x$ & 6.93 \\
\hline $\begin{array}{l}\text { 'Bartwentynine' } \\
\text { White Flame }\end{array}$ & PZ10-236 & A & $14.43 \pm 0.04$ & 1.46 & $2 x$ & 7.22 \\
\hline 'Blue Boy' & PZ12-003 & $\mathrm{F}$ & $14.40 \pm 0.06$ & 1.63 & $2 x$ & 7.20 \\
\hline 'Blue Lagoon' & PZ12-004 & $\mathrm{F}$ & $14.18 \pm 0.37$ & 1.82 & $2 x$ & 7.09 \\
\hline 'Blue Paradise' & PZ10-170 & $\mathrm{F}$ & $14.98 \pm 0.05$ & 1.26 & $2 x$ & 7.49 \\
\hline 'Blushing Bride' & PZ10-090 & $\mathrm{F}$ & $21.35 \pm 0.34$ & 1.97 & $3 x^{\mathrm{u}}$ & 7.12 \\
\hline 'Blushing Shortwood' & PZ10-091 & $\mathrm{F}$ & $14.12 \pm 0.27$ & 1.26 & $2 x$ & 7.06 \\
\hline 'Brigadier' & PZ10-092 & $\mathrm{F}$ & $14.22 \pm 0.04$ & 1.43 & $2 x$ & 7.11 \\
\hline 'Cinderella' & PZ10-089 & $\mathrm{F}$ & $14.12 \pm 0.01$ & 1.48 & $2 x$ & 7.06 \\
\hline 'Crème de Menthe' & PZ12-008 & $\mathrm{F}$ & $14.59 \pm 0.09$ & 1.75 & $2 x$ & 7.30 \\
\hline 'Dodo Hanbury Forbes' & PZ10-085 & $\mathrm{F}$ & $14.00 \pm 0.22$ & 1.53 & $2 x$ & 7.00 \\
\hline 'Darwin's Choice' & PZ12-009 & $\mathrm{F}$ & $14.47 \pm 0.21$ & 1.70 & $2 x$ & 7.24 \\
\hline 'David' & PZ10-029 & $\mathrm{C}$ & $13.93 \pm 0.28$ & 1.45 & $2 x^{\mathrm{u}}$ & 6.97 \\
\hline 'David's Lavender' & PZ10-189 & $\mathrm{F}$ & $14.19 \pm 0.03$ & 1.33 & $2 x$ & 7.10 \\
\hline 'Delta Snow' & PZ10-027 & B & $14.36 \pm 0.29$ & 1.64 & $2 x^{\mathrm{u}}$ & 7.18 \\
\hline 'Dick Weaver' & PZ12-120 & $\mathrm{G}$ & $21.37 \pm 0.24$ & 1.55 & $3 x^{\mathrm{u}}$ & 7.12 \\
\hline 'Dorffreude' & PZ10-084 & $\mathrm{F}$ & $14.25 \pm 0.03$ & 1.71 & $2 x$ & 7.13 \\
\hline 'Dunbar Creek' & PZ12-122 & $\mathrm{G}$ & $14.34 \pm 0.09$ & 1.84 & $2 x$ & 7.17 \\
\hline 'Ending Blue' & PZ10-081 & $\mathrm{F}$ & $14.43 \pm 0.13$ & 1.79 & $2 x$ & 7.22 \\
\hline 'Jules Sandeau' & PZ12-014 & $\mathrm{F}$ & $14.01 \pm 0.02$ & 1.98 & $2 x$ & 7.01 \\
\hline 'Kirmeslander' & PZ12-015 & $\mathrm{F}$ & $13.83 \pm 0.41$ & 2.43 & $2 x$ & 6.92 \\
\hline 'Leo P. Schlageter' & PZ10-066 & $\mathrm{F}$ & $14.45 \pm 0.62$ & 1.66 & $2 x^{\mathrm{u}}$ & 7.23 \\
\hline 'Little Boy' & PZ12-017 & $\mathrm{F}$ & $14.38 \pm 0.13$ & 1.74 & $2 x$ & 7.19 \\
\hline 'Lizzy' & PZ12-018 & $\mathrm{F}$ & $14.02 \pm 0.12$ & 1.79 & $2 x$ & 7.01 \\
\hline 'Lord Clayton' & PZ11-011 & $\mathrm{C}$ & $13.79 \pm 0.29$ & 1.63 & $2 x$ & 6.90 \\
\hline 'Mile High Pink' & PZ10-064 & $\mathrm{F}$ & $13.91 \pm 0.22$ & 1.4 & $2 x$ & 6.96 \\
\hline 'Miss Ellie' & PZ12-019 & $\mathrm{F}$ & $13.97 \pm 0.01$ & 1.75 & $2 x$ & 6.99 \\
\hline 'Miss Holland' & PZ10-067 & $\mathrm{F}$ & $13.81 \pm 0.06$ & 1.37 & $2 x$ & 6.91 \\
\hline 'Miss Kelly' & PZ10-076 & $\mathrm{F}$ & $15.01 \pm 0.20$ & 1.43 & $2 x$ & 7.51 \\
\hline 'Miss Universe' & PZ10-062 & $\mathrm{F}$ & $14.18 \pm 0.30$ & 1.57 & $2 x$ & 7.09 \\
\hline 'Mother of Pearl' & PZ12-021 & $\mathrm{F}$ & $14.19 \pm 0.16$ & 1.58 & $2 x$ & 7.10 \\
\hline 'Mt. Fujiyama' & PZ12-022 & $\mathrm{F}$ & $14.31 \pm 0.43$ & 1.50 & $2 x$ & 7.16 \\
\hline 'Newbird' & PZ10-075 & $\mathrm{F}$ & $14.30 \pm 0.06$ & 1.42 & $2 x$ & 7.15 \\
\hline 'Nicky' & PZ12-023 & $\mathrm{F}$ & $14.76 \pm 0.58$ & 1.41 & $2 x$ & 7.38 \\
\hline 'Old Cellarhole' & PZ10-072 & $\mathrm{F}$ & $14.68 \pm 0.51$ & 1.69 & $2 x$ & 7.34 \\
\hline 'Orange Perfection' & PZ12-024 & $\mathrm{F}$ & $14.31 \pm 0.02$ & 1.75 & $2 x$ & 7.16 \\
\hline 'Picasso' & PZ12-025 & $\mathrm{F}$ & $14.53 \pm 0.09$ & 1.50 & $2 x$ & 7.27 \\
\hline 'Pink Bud' & PZ10-063 & $\mathrm{F}$ & $13.91 \pm 0.34$ & 1.43 & $2 x$ & 6.96 \\
\hline 'Pixie Miracle Grace' & PZ10-178 & $\mathrm{C}$ & $14.02 \pm 0.30$ & 1.40 & $2 x$ & 7.01 \\
\hline
\end{tabular}


Table 2. Continued.

\begin{tabular}{|c|c|c|c|c|c|c|}
\hline Taxa & Accession no. & Source ${ }^{z}$ & $\begin{array}{l}\text { Relative } 2 \mathrm{C} \text { genome } \\
\text { size }[\text { mean } \pm \mathrm{SD}(\mathrm{pg})]^{\mathrm{y}}\end{array}$ & $\mathrm{CV}(\%)^{\mathrm{x}}$ & Ploidy $^{\mathrm{w}}$ & $1 \mathrm{C} x$ genome size $(\mathrm{pg})^{\mathrm{v}}$ \\
\hline 'Red Magic' & PZ12-027 & $\mathrm{F}$ & $14.37 \pm 0.29$ & 1.60 & $2 x$ & 7.19 \\
\hline 'Red Riding Hood' & PZ10-240 & $\mathrm{F}$ & $13.89 \pm 0.48$ & 2.11 & $2 x$ & 6.95 \\
\hline 'Rijnstroom' & PZ10-071 & $\mathrm{F}$ & $13.98 \pm 0.72$ & 1.37 & $2 x$ & 6.99 \\
\hline 'Robert Poore' & $P Z 10-028$ & B & $20.95 \pm 0.13$ & 1.38 & $3 x^{\mathrm{u}}$ & 6.98 \\
\hline 'Sherbert Cocktail' & PZ10-184 & $\mathrm{C}$ & $13.85 \pm 0.21$ & 1.5 & $2 \mathrm{x}$ & 6.93 \\
\hline 'Shorty White' & PZ12-030 & $\mathrm{F}$ & $14.43 \pm 0.08$ & 1.81 & $2 \mathrm{x}$ & 7.22 \\
\hline 'Sir John Falstaff' & PZ12-031 & $\mathrm{F}$ & $14.61 \pm 0.23$ & 1.55 & $2 \mathrm{x}$ & 7.31 \\
\hline 'Spinners' & PZ10-190 & $\mathrm{C}$ & $14.55 \pm 0.03$ & 1.50 & $2 \mathrm{x}$ & 7.26 \\
\hline 'Spitfire' & PZ12-032 & $\mathrm{F}$ & $14.08 \pm 0.42$ & 1.65 & $2 \mathrm{x}$ & 7.04 \\
\hline 'Starfire' & PZ12-033 & $\mathrm{F}$ & $14.24 \pm 0.14$ & 1.86 & $2 \mathrm{x}$ & 7.12 \\
\hline 'Zurstock Rose' & PZ12-038 & $\mathrm{F}$ & $14.27 \pm 0.19$ & 1.73 & $2 \mathrm{x}$ & 7.14 \\
\hline \multicolumn{7}{|l|}{ Phlox $\times$ arendsii } \\
\hline 'Hesperis' & PZ12-011 & $\mathrm{F}$ & $13.90 \pm 0.19$ & 1.95 & $2 x$ & 6.95 \\
\hline 'Ping Pong' & PZ10-176 & $\mathrm{C}$ & $13.79 \pm 0.20$ & 1.38 & $2 x$ & 6.90 \\
\hline \multicolumn{7}{|l|}{ Subsection Phlox } \\
\hline \multicolumn{7}{|l|}{ Phlox carolina } \\
\hline 'Minnie Pearl' & PZ11-012 & $\mathrm{C}$ & $14.08 \pm 0.14$ & 3.08 & $2 x^{\mathrm{u}}$ & 7.04 \\
\hline 'Kim’ & PZ11-017 & $\mathrm{G}$ & $13.86 \pm 0.01$ & 2.00 & $2 x$ & 6.93 \\
\hline \multicolumn{7}{|l|}{ Phlox glaberrima } \\
\hline 'N $\mathrm{N}^{3}$ Hvtke Meske' & PZ11-017 & $\mathrm{D}$ & $15.09 \pm 0.03$ & 1.60 & $2 x$ & 7.55 \\
\hline ' $\mathrm{N}^{3}$ Springfall' & PZ10-103 & $\mathrm{D}$ & $14.62 \pm 0.03$ & 1.83 & $2 x$ & 7.31 \\
\hline \multicolumn{7}{|l|}{ Phlox maculata } \\
\hline 'Natascha' & PZ10-035 & $\mathrm{B}$ & $14.23 \pm 0.02$ & 1.74 & $2 x$ & 7.12 \\
\hline 'Flower Power' & PZ10-235 & A & $14.31 \pm 0.09$ & 1.42 & $2 x$ & 7.16 \\
\hline 'Rosalinde' & PZ12-029 & $\mathrm{F}$ & $14.63 \pm 0.57$ & 2.03 & $2 \mathrm{x}$ & 7.32 \\
\hline \multicolumn{7}{|l|}{ Phlox pulchra } \\
\hline ‘Eco Pale Moon’ & PZ10-102 & $\mathrm{C}$ & $13.83 \pm 0.01$ & 1.19 & $2 x$ & 6.92 \\
\hline \multicolumn{7}{|l|}{ Phlox Suffruticosa Group } \\
\hline 'Miss Lingard' & PZ10-245 & $\mathrm{F}$ & $21.21 \pm 0.04$ & 1.00 & $3 x^{\mathrm{u}}$ & 7.07 \\
\hline 'Monica Lynden-Bell' & PZ12-020 & $\mathrm{F}$ & $14.28 \pm 0.26$ & 1.67 & $2 x$ & 7.14 \\
\hline
\end{tabular}

${ }^{\mathrm{z}} \mathrm{A}=$ Forestfarm at Pacifica (Williams, OR), B = Growild, Inc. (Fairview, TN), C $=$ Millcreek Gardens, $($ Ostrander, OH), D $=$ Nearly Native Nursery, Inc. (Fayetteville, GA), E = Ornamental Plant Germplasm Center (Columbus, OH), F = Perennial Pleasures Nursery (East Hardwick, VT), $\mathrm{G}=$ Plant Delights Nursery (Raleigh, NC), H = The Primrose Path (Scottdale, PA), I = Proven Winners (Sycamore, IL).

${ }^{\mathrm{y}}$ Holoploid genome sizes were determined with propidium iodide as the fluorochrome.

${ }^{\mathrm{x}}$ Coefficient of variation.

w $2 x=$ diploid, $3 x=$ triploid, $4 x=$ tetraploid.

v $1 \mathrm{C} x$ values were calculated as $2 \mathrm{C}$ value/ploidy level.

uploidy levels were confirmed by chromosome counts in our laboratory.

enhanced ornamental attributes, as evidenced by the inadvertent selection of such lines, and may have greater adaptive importance than previously described.

The mean 1Cx genome size of the eastern Phlox taxa in this study, $7.01 \mathrm{pg}$ (Tables 2 and 3) is higher than those of other
Phlox species that have been examined thus far. Phlox pilosa of subsection Divaricatae had a $1 \mathrm{C} x$ value ranging from 5.49 to $5.70 \mathrm{pg}$; the P. amabilis $-P$. woodhousei complex of subsection Speciosae from 4.26 to $4.36 \mathrm{pg}$; and the P. nana complex from 3.49 to $3.83 \mathrm{pg}$ (Fehlberg and Ferguson, 2012a; Worcester 
Table 3. Relative holoploid (2C) and monoploid (1Cx) genome sizes, and inferred ploidy levels, for a wild-collected accession of Phlox taxa (section Phlox, subsections Paniculatae and Phlox). Genome size was determined using flow cytometry and inferred ploidy was confirmed by chromosome counts of selected samples.

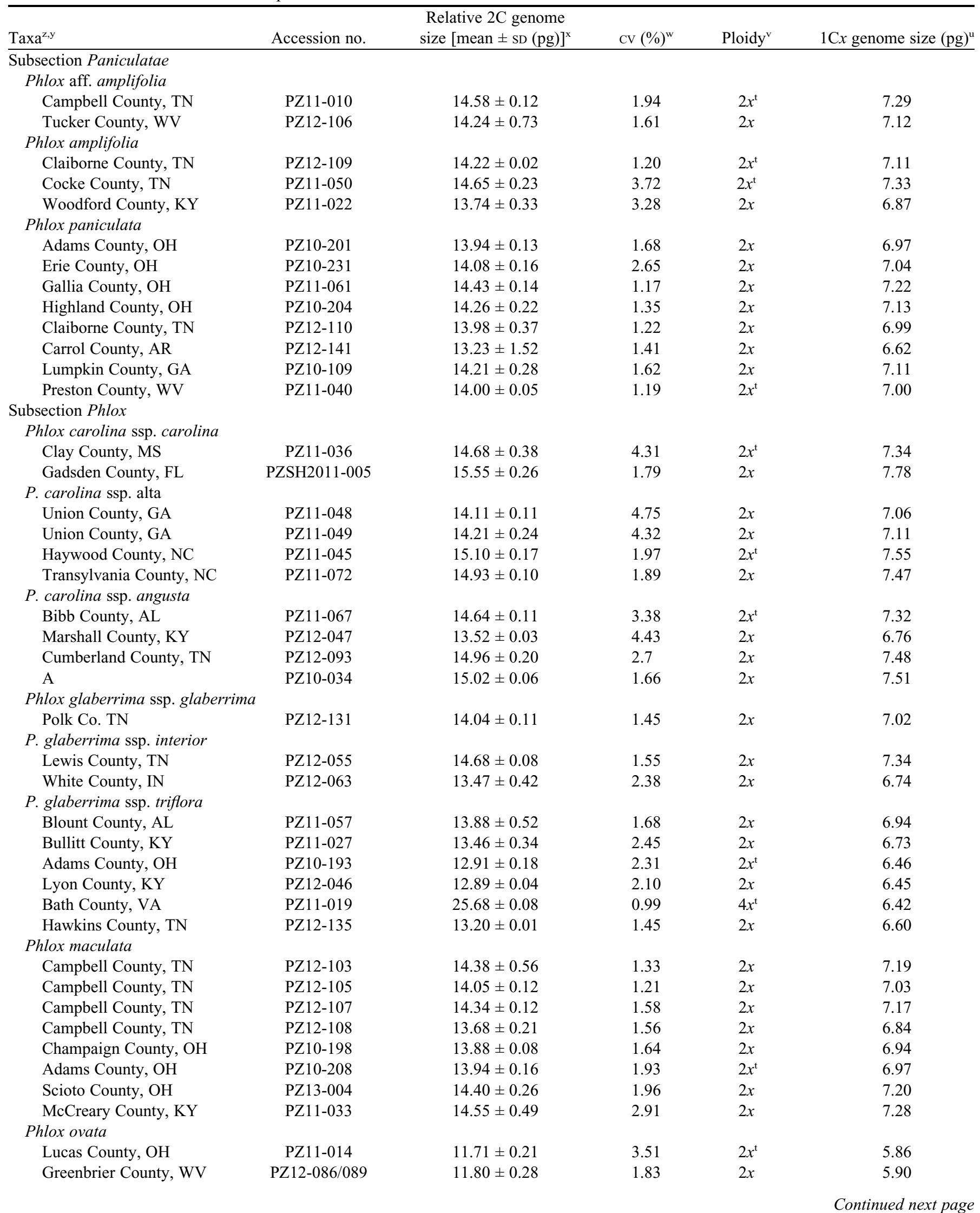


Table 3. Continued.

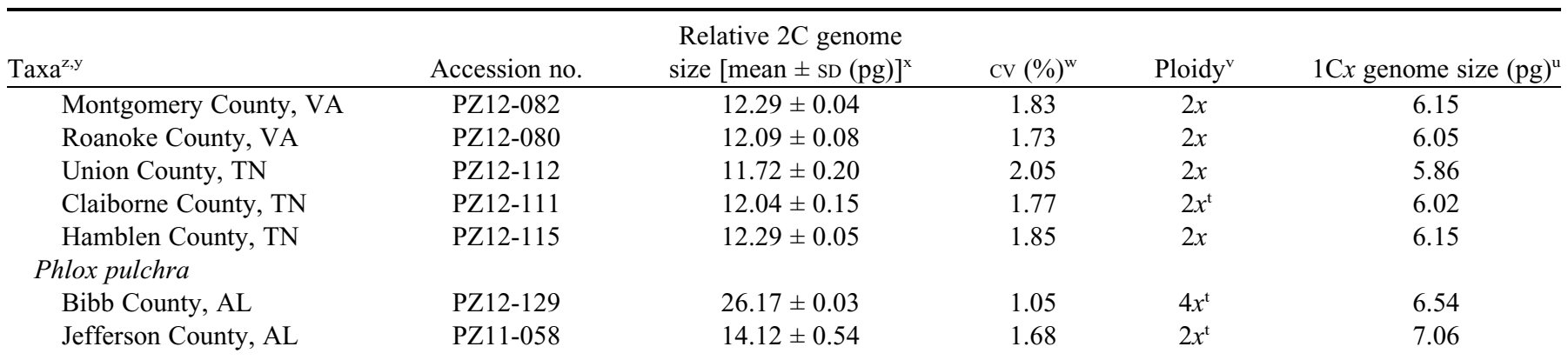

${ }^{\mathrm{z} C o l l e c t i o n s ~ w e r e ~ m a d e ~ f r o m ~ w i l d ~ p o p u l a t i o n s ~ b y ~ t h e ~ f i r s t ~ a u t h o r ~ f r o m ~} 2010$ to 2013 . The county of origin is provided where known; A $=$ plant obtained from North Creek Nursery (Landenburg, PA) from a wild source in eastern Georgia.

yPositive identifications were made using the taxonomic keys of Locklear (2011) and Wherry (1955) and comparison with herbarium specimens. ${ }^{x}$ Holoploid genome sizes were determined with propidium iodide as the fluorochrome.

${ }^{\mathrm{w}}$ Coefficient of variation.

v $2 x=$ diploid, $4 x=$ tetraploid.

u $1 \mathrm{C} x$ values were calculated as $2 \mathrm{C}$ value/ploidy level.

tPloidy levels were confirmed by chromosome counts in our laboratory.

et al., 2012; Wright, 2014). Other western species such as $P$. aculeata, $P$. caryophylla, $P$. cluteana, $P$. longifolia, and $P$. stansburyi had a $1 \mathrm{C} x$ value ranging from 3.66 to $5.48 \mathrm{pg}$ (Fehlberg and Ferguson, 2012b). This nearly 2-fold range of $1 \mathrm{C} x$ values applies to diploid, tetraploid, pentaploid, and hexaploid cytotypes found among some of these species. Within other genera of the Polemoniaceae, the only genome size estimates we could find include Navarretia squarrosa, $1 \mathrm{C} x=1.32 \mathrm{pg}$, and Collomia grandiflora, $1 \mathrm{C} x=2.08 \mathrm{pg}$ (Bennett and Leitch, 2012). The genome size for Phlox is within the same order of magnitude for the size of the majority of angiosperms whose average $1 \mathrm{C} x$ value is $5.9 \mathrm{pg}$, although there is a 2400 -fold range in size within the clade (Bennett and Leitch, 2012).

Genome size differences have been proposed as one feature that can distinguish species in a large genus like Penstemon (Broderick et al., 2011), but we could not use this measure to distinguish the species in our survey. Mean genome sizes of the two species in subsection Paniculatae were indistinguishable $(2 \mathrm{C}=14.02 \mathrm{pg}$ for $P$. paniculata, $2 \mathrm{C}=14.29 \mathrm{pg}$ for $P$. amplifolia) whereas size variation in subsection Phlox was more pronounced. While the average $2 \mathrm{C}$ values at the diploid level $(2 n=2 x=14)$ for $P$. carolina, P. glaberrima, P. maculata, and $P$. pulchra ranged from 13.57 to $14.67 \mathrm{pg}$, the variation within the $P$. carolina- $P$. glaberrima complex, approaching $20.5 \%$, represents considerable within-species variation and may be related to subtle morphological differences and ecotypic divergence seen in these and other taxa (Ceccarelli et al., 2011; Cires et al., 2009). Such variation underscores the taxonomic uncertainty in this group and precludes use of the estimates of genome size to distinguish between the members of the complex. Comparable variation in genome size was also found among taxa in the P. pilosa complex, but not among other taxa analyzed in this study (Tables 2 and 3; Worcester et al., 2012).

Among diploids, variation in genome size $(28.1 \%)$ of subsection Phlox far exceeds the "normal" range of variation (3\%) that is exhibited by other angiosperm species (Bennett and Leitch, 2005; Gurushidze et al., 2012; Soltis et al., 2003). Initial molecular reconstructions of the $P$. carolina-glaberrima complex phylogeny using ITS and cpDNA restriction sites resulted in a paraphyletic group that involved members of subsections Divaricatae, Paniculatae, and Phlox. Hence, these studies failed to provide resolution and taxonomic stability of these species. Hybridization was implicated as the cause of the paraphyletic grouping; however, it is also possible that Phlox taxa have recently diverged and that the markers used were not sufficient to capture a strong phylogenetic signal. The variation in genome size suggested that recent treatments of this complex, that have reduced the number of subspecies, might not accurately reflect the evolutionary and taxonomic history of the morphologically variable and geographically widespread complex of taxa.

The analysis of genome size of $P$. paniculata cultivars revealed that four of 66 cultivars $(6 \%)$ had genome sizes larger than diploid, and the chromosome counts indicated they were triploid. Such triploid cytotypes have not been previously described for this species, but evidence from related species and from hybridization experiments suggests they are derived from crosses between diploid and tetraploid cytotypes (Fehlberg and Ferguson, 2012a; Flory, 1934; Zale, 2014). Tetraploid $P$. paniculata were not identified among the wild-collected accessions analyzed in this study, but population sampling was not exhaustive, and large portions of the species' geographic range were not covered. The recent discovery of polyploid populations of other eastern Phlox taxa in related subsections, at the edges of their respective geographic distribution, suggests that targeted sampling along the perimeter of the geographic range of $P$. paniculata may reveal polyploid populations (Fehlberg and Ferguson, 2012a; Worcester et al., 2012; Wright, 2014; Zale, 2014). The east-west geographic distribution of $P$. paniculata stretches from the eastern Pennsylvania-New Jersey border to northwestern Arkansas; this species can be abundant in certain localities, and extensive phenotypic variation has been noted in wild populations (Locklear, 2011; Symons-Jeune, 1953; Wherry, 1955). Wild-sourced polyploid germplasm, should it be found, could be used to verify the products of $F_{1}$ interploid crosses and have the potential to benefit Phlox breeding programs. Introduction of wild-collected germplasm can also result in genotypes not currently in cultivation and can be useful in systematic studies to discern the evolutionary history of the species. 


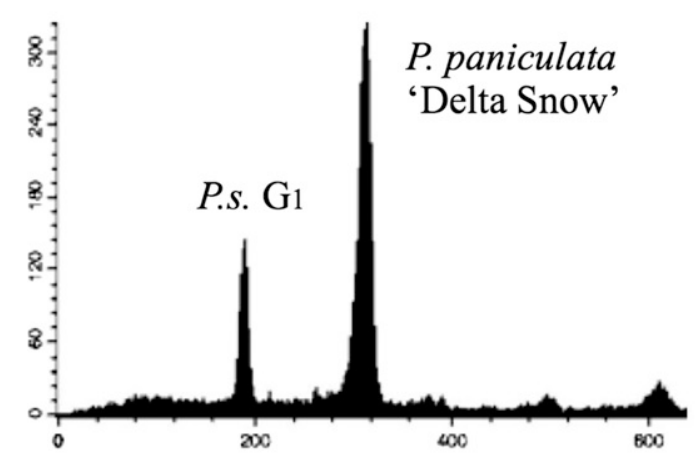

A

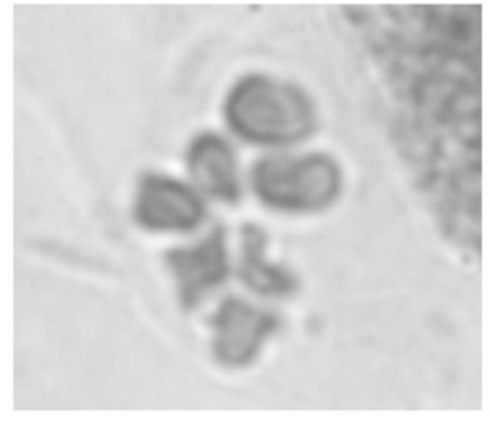

$$
2 n=2 x=14
$$

$\mathrm{B}$

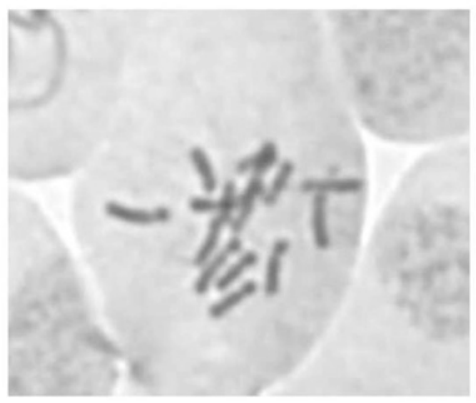

$$
2 n=2 x=14
$$

$\mathrm{C}$

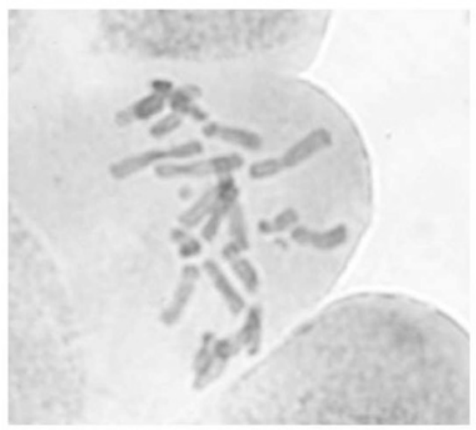

$$
2 n=3 x=21
$$
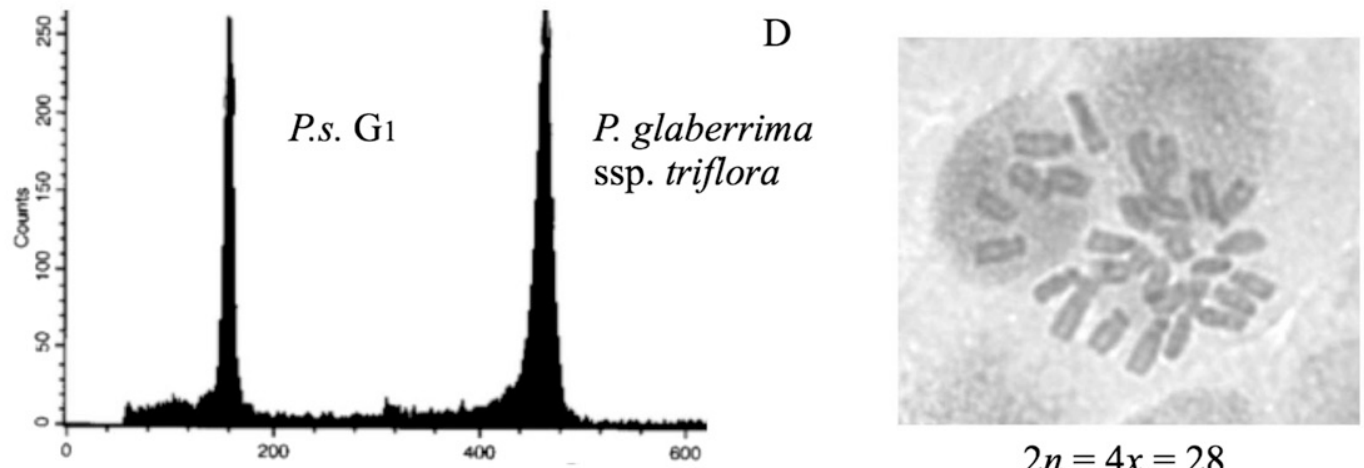

$$
2 n=4 x=28
$$

\section{Relative DNA fluorescence}

Fig. 2. Flow cytometric determination of holoploid genome size and ploidy level of diploid $(2 n=2 x=14)$, triploid $(2 n=3 x=21)$, and tetraploid $(2 n=4 x=28)$ cultivars of Phlox paniculata and $P$. amplifolia using Pisum sativum 'Ctirad' as the internal standard. (A) Histogram and meiotic metaphase chromosome counts for the diploid P. paniculata 'Delta Snow' $(2 \mathrm{C}=14.36 \mathrm{pg})$. (B) Histogram and mitotic metaphase chromosome counts for the diploid $P$. amplifolia $\mathrm{PZ11}-050$ (2C $=$ $14.65 \mathrm{pg})$; (C) Histogram and mitotic metaphase chromosome count of the triploid P. paniculata 'John Fanick' $(2 \mathrm{C}=21.75 \mathrm{pg})$; (D) Histogram and mitotic metaphase chromosome count of the tetraploid P. glaberrima ssp. triflora PZ11-019 (2C $=25.68 \mathrm{pg})$. 
A. B. C. D.

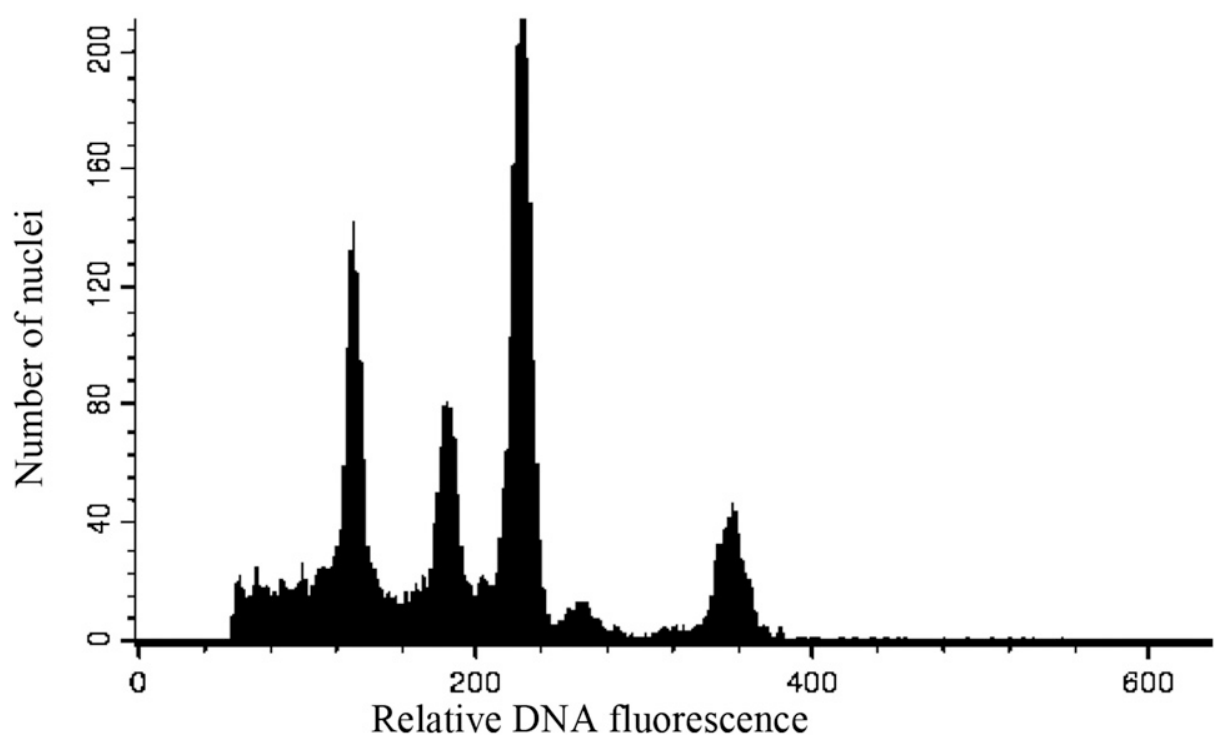

Fig. 3. Concurrent comparison of four Phlox species from three sections and four different subsections of the genus: (A) diploid P. subulata, (B) diploid P. pilosa ssp. pilosa, (C) diploid P. paniculata, and (D) tetraploid P. buckleyi. $\mathrm{G}_{1}$ peak placement and values support data from analyses of the same individual samples with an internal standard.

An interesting observation about the triploid cultivars is that 'Robert Poore' and 'John Fanick' are consistently rated among the $P$. paniculata cultivars most resistant to powdery mildew (Hawke, 1999, 2011; Taylor et al., 2002). Susceptibility to powdery mildew (Erysiphe cichoracearum) is the foremost factor limiting more widespread usage of $P$. paniculata in landscapes, but despite the popularity of this species, a definitive mode of resistance has yet to be identified (Hawke, 1999; Jorosz et al., 1982). There are highly mildew-resistant diploid cultivars such as Shortwood, David, and Delta Snow (Bir 1999, 2003; Hawke, 1999, 2011), so resistance in this species may have different pathways that potentially involve morphological adaptations, physiological alterations, specific $R$-gene action, or environmental interactions (Jorosz et al., 1982). While no studies directly link polyploidy to disease resistance in plants, genetic variation generated through interploid crosses may provide a strategy to develop mildew-resistant

Table 4. Monoploid (1Cx) genome sizes of Phlox taxa from subsections Paniculatae and Phlox determined using flow cytometry, grouped by subsection and species.

\begin{tabular}{cclc}
\hline Subsection & $\begin{array}{c}\text { 1Cx } \\
{[\mathrm{mean} \pm \mathrm{sD}(\mathrm{pg})]}\end{array}$ & \multicolumn{1}{c}{$\begin{array}{c}\text { Species } \\
{[\mathrm{mean} \pm \mathrm{sD}(\mathrm{pg})]}\end{array}$} \\
\hline Paniculatae & $7.01 \pm 0.36 \mathrm{a}^{\mathrm{z}}$ & $\begin{array}{l}\text { amplifolia } \\
\text { paniculata }\end{array}$ & $7.10 \pm 0.18 \mathrm{a}$ \\
& & $7.10 \pm 0.15 \mathrm{a}$ \\
Phlox & \multirow{2}{*}{$6.85 \pm 0.49 \mathrm{~b}$} & carolina $^{\mathrm{y}}$ & $7.28 \pm 0.30 \mathrm{a}$ \\
& & glaberrima & $6.71 \pm 0.40 \mathrm{~b}$ \\
& & maculata & $7.11 \pm 0.15 \mathrm{a}$ \\
& & ovata & $5.99 \pm 0.13 \mathrm{c}$ \\
& & pulchra & $6.84 \pm 0.27 \mathrm{~b}$
\end{tabular}

${ }^{\mathrm{z}}$ Values separated within columns using the Fishers least significant difference with $P<0.05$.

${ }^{\mathrm{y}}$ Includes all botanical varieties described for these species listed in Table 4. plants. Data from a variety of ornamental and agronomic crops indicate that resistance to this obligate pathogen is controlled by one to several $R$-genes or alleles and that genetic buffering found in some polyploids may be responsible for resistance of different plant organs (Cohen et al., 2003; Comai, 2005; Kessler et al., 2010). This finding is highly speculative, and further testing for modes of mildew resistance is needed for $P$. paniculata, but the results presented here suggest that polyploid breeding may offer an option.

Triploids and pentaploids are rare in Phlox (Fehlberg and Ferguson, 2012a; Flory, 1934; Meyer, 1944). Only the hybrid Phlox Suffruticosa Group 'Miss Lingard', reportedly the product of a cross between $P$. carolina $\times P$. maculata, has been shown to be triploid, although the parentage has not been confirmed (Locklear, 2011; Meyer, 1944; Wherry, 1935a). Our analysis of genome size for this cultivar shows that the 21.21-pg $2 \mathrm{C}$ size is consistent with a triploid level, supporting a hybrid origin from a cross of a tetraploid and a diploid parent. While no tetraploids were found among our survey of accessions from wild populations and cultivars of plants keyed to $P$. carolina and $P$. maculata, the morphological similarity and historical taxonomic confusion of taxa of the $P$. glaberrima complex suggests that 'Miss Lingard' may have resulted from a cross between a tetraploid $P$. glaberrima and diploid $P$. maculata. Tetraploid cytotypes were found among $P$. glaberrima cultivars tested in this study and are known to occur in natural populations in the southern Appalachian Mountains; it is possible that early horticultural introductions originated in this area (Ferguson, 1998; Wherry, 1955). The hybrid origin of 'Miss Lingard' is also supported by pollen sterility in the tested clones and failure to set seed in hybrid crosses (Wherry, 1935a). The presence of pentaploids among populations of taxa in the $P$. amabilis $-P$. woodhousei complex suggests that crosses between individuals of different ploidy may be more widespread among Phlox than previously known (Fehlberg and Ferguson, 2012a).

Genome size measurements of Phlox xarendsii lead us to question the identification of this hybrid in the trade. Cultivars listed as Phlox $\times$ arendsii had genome size and phenology that was the same as other $P$. paniculata cultivars. This hybrid species is considered to have originated from a cross of $P$. paniculata with P. divaricata (Arends, 1912; Wherry, 1955). These species differ in genome size, with $P$. divaricata having a $2 \mathrm{C}$ size of $\approx 9$ to $10 \mathrm{pg}$ which is $30 \%$ lower than $P$. paniculata (Zale, 2014). Controlled hybridization between these two species done at the OPGC shows the hybrids to have a genome intermediate between the parents, and pollen sterility; the hybrids also flowered much earlier than the $P$. paniculata parent (Zale, 2014). Thus, it appears that current cultivars labeled as $P$. ×arendsii may either be variants of $P$. paniculata 
or are backcross progeny of $P$. paniculata; a conclusion further supported by the observation that viable seed was produced after open pollination in such cultivars (Wherry, 1955). However, only a small subset of $P$. ×arendsii cultivars was tested. Many more exist, and it is possible that some may represent interspecific hybrids derived from multiple origins.

There has been one previous report of polyploidy in taxa of subsection Phlox, a tetraploid individual of $P$. glaberrima collected from the southern Appalachians (Ferguson, 1998). We have now identified six tetraploid accessions in subsection Phlox: five in P. glaberrima ssp. triflora and one in P. pulchra. This is the first report of polyploidy among cultivars of subsection Phlox, and the first report of a tetraploid cytotype of $P$. pulchra (Table 3). The tetraploid $P$. pulchra has the largest genome size among all Phlox taxa measured to date $(2 \mathrm{C}=26.17$ $\mathrm{pg}$ ) that were part of a large survey of such genomes in wild and cultivated Phlox (Zale, 2014). The tetraploid P. glaberrima cultivars 'Anita Kistler' and 'Morris Berd' are known to have been collected directly from natural populations, and the remaining tetraploid cultivars are not likely to be more than one generation removed from wild-collected progenitors (Bendtsen, 2009; Fuchs, 1994). All of these selections were probably made without the knowledge of ploidy, and suggest inadvertent selection for polyploid plants because of novel phenotypic traits or increased adaptation and persistence in a range of environmental conditions. Furthermore, all of the $P$. glaberrima cultivars can be attributed to the morphologically distinct taxon $P$. glaberrima ssp. triflora. Together with $P$. ovata and P. pulchra, this taxon displays midspring (MayJune) phenology; a proliferation of sterile, evergreen stems; and a preference for xeric habitats (Table 1). These morphological similarities between the three species distinguish them from others in the subsection Phlox. The presence of polyploidy among these, but not other taxa in the subsection, suggests that ploidy may be an additional differentiating factor between these and other species (Michaux, 1803; Ferguson et al., 1999; Smith and Levin, 1967). Such observations highlight the importance of introducing wild-collected Phlox germplasm to increase the genetic diversity of available ornamental crops and identify avenues for polyploid breeding of Phlox.

Identification of triploid $P$. paniculata cultivars indicates that ploidy manipulation has already occurred in Phlox, either deliberately or inadvertently. Induced tetraploids have been developed in P. drummondii (Raghuvanshi and Pathak, 1975; Tiwari and Mishra, 2012; Vyas et al., 2007), P. paniculata (Matiska and Vejsadová, 2010), and P. subulata (Zhang et al., 2008), but the extent to which these have contributed to new cultivars is unclear. There is room for further experimentation and manipulation of polyploidy in this important genus, perhaps to alter flowering characteristics (flower size, longevity, and flowering period) and size and vigor (Dar et al., 2013). Sterile interspecific hybrids may also be restored to fertility by allopolyploidization (Leus et al., 2012).

The analysis of genome size in cultivars and wild forms of $P$. paniculata and its long-styled relatives provides further insight into the natural diversity and the horticultural manipulation of this group of ornamental plants. Although most accessions were diploid, the presence of triploid cultivars that likely originated from crosses between diploid and tetraploid parental taxa suggests that ploidy manipulation could be useful in breeding Phlox. Tetraploids were more abundant among cultivars than wild-collected accessions indicating that polyploids probably have been inadvertently selected for horticultural purposes, and thus a more deliberate effort to alter ploidy may be warranted. This information is likely to be of use to plant breeders, systematists, and plant biologists.

\section{Literature Cited}

Arends, J. 1912. Phlox arendsii. Proc. Royal Hort. Soc. 38:151.

Arugumanathan, K. and E.D. Earle. 1991. Estimation of nuclear DNA content of plants by flow cytometry. Plant Mol. Biol. Rpt. 9:229-241.

Balao, F., R. Casimiro-Soriguer, M. Talavera, J. Herrera, and S. Talavera. 2009. Distribution and diversity of cytotypes in Dianthus broteri as evidenced by genome size variations. Ann. Bot. (Lond.) 104:965-973.

Bendtsen, B.H. 2009. Phlox: Phloxe fur den garten. Forlaget Geranium Press, Viborg, Denmark.

Bennett, M.D. and I.J. Leitch. 2005. Plant genome size research: A field in focus. Ann. Bot. (Lond.) 95:1-6.

Bennett, M.D. and I.J. Leitch. 2012. Plant DNA $C$-values Database (release 6.0, Dec. 2012). 20 Aug. 2014. <http://www.kew.org/ cvalues/>.

Bir, R.E. 1999. Phlox without fail. Organic Gardening 46:52-55.

Bir, R.E. 2003. Phlox get humidity test. Amer. Gardener 82:19.

Broderick, S.R., M.R. Stevens, B. Geary, S.L. Love, E.N. Jellen, R.B. Dockter, S.L. Daley, and D.T. Lindgren. 2011. A survey of Penstemon's genome size. Genome 54:160-173.

Ceccarelli, M., V. Sarri, M.E. Caceres, and P.G. Cionini. 2011. Intraspecific genotypic diversity in plants. Genome 54:701-709.

Cires, E., C. Cuesta, E.L. Peredo, M. Aì. Revilla, and J.A.F. Prieto. 2009. Genome size and morphological differentiation within Ranunculus parnassifolius group (Ranunculaceae) from calcareous screes in the northwest of Spain. Plant Syst. Evol. 281:193-208.

Cohen, R., A. Hanan, and H.S. Paris. 2003. Single-gene resistance to powdery mildew in zucchini squash (Cucurbita pepo). Euphytica 130:433-441.

Comai, L. 2005. The advantages and disadvantages of being polyploid. Nat. Rev. Genet. 6:836-846.

Contreras, R.N., J.M. Ruter, and W.W. Hanna. 2009. An oryzalininduced autoallooctoploid of Hibiscus acetosella 'Panama Red'. J. Amer. Soc. Hort. Sci. 134:553-559.

Dar, T.H., S.N. Raina, and S. Goel. 2013. Molecular analysis of genomic changes in synthetic autotetraploid Phlox drummondii Hook. Bot. J. Linn. Soc. 110:591-605.

Deam, C.C. 1940. The flora of Indiana. Div. Forestry, Indiana Dept. Conservation, Indianapolis, IN.

Doležel, J. 2009. Determination of nuclear genome size. 10 Sept. 2011. $<\mathrm{http}$ ://olomouc.ueb.cas.cz/book/determination-nuclear-genome-size $>$.

Doležel, J., J. Greilhuber, S. Lucretti, A. Meister, M.A. Lysák, L. Nardi, and R. Obermayer. 1998. Plant genome size estimation by flow cytometry: Interlaboratory comparison. Ann. Bot. (Lond.) 82:17-26.

Eeckhaut, T., K. van Laere, J. De Riek, and J. van Huylenbroek. 2006. Overcoming barriers in floriculture, ornamental and plant biotechnology, Vol. I. Global Science Books. Cambridge Univ. Press, Cambridge, UK.

Fehlberg, S.D. and C.J. Ferguson. 2012a. Intraspecific cytotypic variation and complex genetic structure in the Phlox amablis $-P$. woodhousei (Polemoniaceae) complex. Amer. J. Bot. 99:865-874.

Fehlberg, S.D. and C.J. Ferguson. 2012b. Intraspecific cytotype variation and conservation: An example from Phlox (Polemoniaceae). Calochortiana 1:189-195.

Ferguson, C.J. 1998. Molecular systematics of eastern Phlox species. PhD Thesis, Univ. Texas, Austin, TX.

Ferguson, C.J. and R.K. Jansen. 2002. A chloroplast DNA phylogeny of eastern Phlox (Polemoniaceae): Implications of congruence and incongruence with the ITS phylogeny. Amer. J. Bot. 89:1324-1335.

Ferguson, C.J., F. Krämer, and R.K. Jansen. 1999. Relationships of eastern North American Phlox (Polemoniaceae) based on ITS sequence data. Syst. Bot. 24:616-631. 
Flory, W.S., Jr. 1931. Chromosome numbers in Phlox. Amer. Nat. 65:473-476.

Flory, W.S., Jr. 1934. A cytological study on the genus Phlox. Cytologia (Tokyo) 6:1-18.

Fuchs, H. 1994. Phlox stauden and polsterphloxe. Eugen Ulmer, Stuttgart, Germany.

Greilhuber, J. and I.J. Leitch. 2013. Genome size and the phenotype. Plant Genome Diversity 2:320-344.

Greilhuber, J., E.M. Temsch, and J.C.M. Loureiro. 2007. Nuclear DNA content measurements, p. 67-101. In: J. Doležel, J. Greilhuber, and J. Suda (eds.). Flow cytometry with plant cells: Analysis of genes, chromosomes and genomes. Wiley-Verlag, Weinheim, Germany.

Gurushidze, M., J. Fuchs, and F.R. Blattner. 2012. The evolution of genome size variation in drumstick alliums (Allium subgenus Melannocrommyum). Syst. Bot. 37:96-104.

Hawke, R.G. 1999. Plant evaluation notes: An evaluation report of selected Phlox species and hybrids. Chicago Hort. Soc. 13:1-4.

Hawke, R.G. 2011. A comparative study of Phlox paniculata cultivars. Plant Evaluation Notes. Chicago Botanic Garden 35:1-10.

Hawke, R.G. 2013. Fabulous phlox. 29 Oct. 2013. <http:/greenhousemag. com/gm1113-fabulous-garden-phlox.aspx>.

Hogenboom, N.G. and K. Mather. 1975. Incompatibility and incongruity: Two different mechanisms for the non-functioning of intimate partner relationships (and comments). Proc. R. Soc. Lond. 188:361-375.

Jorosz, A.M., M. Sheets, and M. Levy. 1982. Cuticle thickness in Phlox and resistance to powdery mildew: An unreliable line of defense. Amer. J. Bot. 69:824-828.

Kessler, S.A., H. Shimosato-Asano, N.F. Keinath, S.E. Wuest, G. Ingram, R. Panstruga, and U. Grossniklaus. 2010. Conserved molecular components for pollen tube reception and fungal infection. Science 330:968-971.

Leus, L., T. Eeckhaut, E. Dhooghe, M.C. van Labeke, K. van Laere, and J. van Huylenbroeck. 2012. Polyploidy breeding in vitro: Experiences with ornamentals. Acta Hort. 961:235-238.

Levin, D.A. 1966. The Phlox pilosa complex: Crossing and chromosome relationships. Brittonia 18:142-162.

Lierval, M. 1866. Culture pratique des Phlox, par Lierval. E. Dounnaud, Paris, France.

Locklear, J.H. 2011. Phlox: A natural history and gardener's guide. Timber Press, Portland, OR.

Matiska, P. and H. Vejsadová. 2010. Polyploidy induction in Phlox paniculata under in vitro conditions. Acta Univ. Agr. Silvic. Mendel. Brun. 58:101-106.

Meyer, J.R. 1944. Chromosome studies of Phlox. Genetics 29:199-216. Michaux, A. 1803. Flora boreali-americana, Sistens Characteres Plantarum quas in America septentrionali collegit et detexit. Levrault, Paris, France.

Parris, J.K., T.G. Ranney, H.T. Knap, and W.V. Baird. 2010. Ploidy levels, genomes sizes, and base pair composition in Magnolia. J. Amer. Soc. Hort. Sci. 135:533-547.
Pridham, A.M.S. 1934. History, culture, and varieties of summerflowering phloxes. Cornell Univ. Agr. Expt. Sta. Bul. 588.

Raghuvanshi, S.S. and C.S. Pathak. 1975. Polyploid breeding and possibility of raising double varieties in Phlox drummondii. Hook. Cytologia 40:355-363.

Ranney, T.G. 2006. Polyploidy: From evolution to new plant development. Proc. Intl. Plant Prop. Soc. 56:137-142.

Šmarda, P. and P. Bureš. 2010. Understanding intraspecific variation in genome size in plants. Preslia 82:41-61.

Smith, D.M. and D.A. Levin. 1967. Karyotypes of eastern North American Phlox. Amer. J. Bot. 54:324-334.

Soltis, D.E., P.S. Soltis, M.D. Bennett, and I.J. Leitch. 2003. Evolution of genome size in the angiosperms. Amer. J. Bot. 90:1596-1603.

Symons-Jeune, B.H.B. 1953. Phlox: A flower monograph. D. Van Nostrand, New York, NY.

Taylor, E., R. Cartwright, J. Robbins, G. Klingaman, and J. Lindstrom. 2002. Evaluation of Phlox paniculata L. cultivars for susceptibility to powdery mildew. Proc. Southern Nursery Assn. Res. Conf. 47:194-198.

Tiwari, A.K. and S.K. Mishra. 2012. Effect of colchicine on mitotic polyploidization and morphological characteristics of Phlox drummondii. Afr. J. Biotechnol. 11:9336-9342.

Vyas, P., M.S. Bisht, S. Miyazawa, S. Yano, K. Noguchi, I. Terashima, and S. Funayama-Noguchi. 2007. Effects of polyploidy on photosynthetic properties and anatomy in leaves of Phlox drummondii. Funct. Plant Biol. 34:673-682.

Wherry, E.T. 1932a. The eastern long-styled phloxes, part 1. Bartonia 13:18-37.

Wherry, E.T. 1932b. The eastern long-styled phloxes, part 2. Bartonia 14:14-26.

Wherry, E.T. 1933. The eastern veiny-leaved phloxes. Bartonia 15:14-26. Wherry, E.T. 1935a. Our native phloxes and their horticultural derivatives. National Hort. Mag. 14:209-231.

Wherry, E.T. 1935b. A new variety of Phlox ovata from the Alabama Mountains. Bartonia 16:37-39.

Wherry, E.T. 1945. The Phlox carolina complex. Bartonia 23:1-9.

Wherry, E.T. 1955. The genus Phlox. Morris Arboretum Monogr., Philadelphia, PA.

Worcester, L., M.H. Mayfield, and C.J. Ferguson. 2012. Cytotypic variation in Phlox pilosa ssp. pilosa (Polemoniaceae) at the western edge of its range in the central United States. J. Bot. Res. Inst. Texas 6:443-451.

Wright, B.A. 2014. Systematic studies in the genus Phlox (Polemoniaceae): Cytotypic variation in Phlox nana Nutt. And utility of a low copy nuclear gene region (IDBH) for phylogeny development. Master's Thesis, Kansas State Univ., Manhattan, KS.

Zale, P.J. 2014. Germplasm development, characterization, and enhancement of eastern Phlox species. Ph.D. Diss., Ohio State Univ., Columbus, $\mathrm{OH}$.

Zhang, Z., H. Dai, M. Xiao, and X. Liu. 2008. In vitro induction of tetraploids in Phlox subulata L. Euphytica 159:59-65. 